\title{
Prohibiting Sex Discrimination in the Workplace: An Economic Perspective
}

\author{
John J. Donohue III†
}

Much has changed in the 25 years since conservative Southern congressmen attempted to derail Title VII of the 1964 Civil Rights Act by offering an amendment that would extend its prohibitions to employment discrimination against women. ${ }^{1}$ It is difficult to capture in the dry text the mocking condescension with which Congressman Smith of Virginia offered the amendment as his supporters chortled their approval:

Mr. Chairman, this amendment is offered to the fair employment practices title of this bill to include within our desire to prevent discrimination against another minority group, the women, but a very essential minority group, in the absence of which the majority group would not be here today.

Now, I am very serious about this amendment ... I do not think it can do any harm to this legislation; maybe it will do some good. I think it will do some good for the minority sex. $^{2}$

To the delight of his supporters, Congressman Smith then quoted from a letter he claimed to have received from a female constituent disturbed by the numerical superiority of women to men, which undermined "our spinster friends in their 'right' to a nice husband and family." Congressman Smith concluded,

† Associate Professor of Law, Northwestern University School of Law, and Research Fellow, American Bar Foundation. I would like to thank Ian Ayres, Mayer Freed, Keith Hylton, Beth Mertz, Daniel Polsby, Cass Sunstein, Peter Siegelman, Tom Tyler, David Van Zandt, and participants at a Fellows Seminar at the American Bar Foundation for their helpful comments on an earlier version of this paper.

1 The original version of Title VII only prohibited employment discrimination based on race, color, religion, or national origin. U.S. Equal Employment Opportunity Commission (EEOC), The Legislative History of Titles VII and XI of the Civil Rights Act of 19643213 (1968) ("EEOC, Legislative History").

2 Id.

3 Id. Congressman Smith introduced this letter as follows:

[T]o show you how some of the ladies feel about discrimination against them, I want to read you an extract from a letter that $I$ received the other day. This lady has a real grievance on behalf of the minority sex. She said that she had seen that I was going to present an amendment to protect the most important sex, and she says: "I 
I read that letter just to illustrate that women have some real grievances and some real rights to be protected. I am serious about this thing. I just hope that the committee will accept it. Now, what harm can you do this bill that was so perfect yesterday and is so imperfect today-what harm will this do to the condition of the bill? ${ }^{4}$

Despite the absence of any hearings or even a single word of testimony on the issue of sex discrimination, the House accepted the amendment, which was subsequently retained by the Senate. Thus was born the law forbidding employment discrimination against women. ${ }^{5}$

\section{Attitudes-On Women, Discrimination, and Law}

This story reflects a set of attitudes-that women in the workplace are not to be taken seriously, that they are more concerned with achieving financial security through obtaining husbands than through work-that thankfully has lost currency in the last two and a half decades. All the boors have not been rousted, from Congress or elsewhere, but attitudes toward women in the workplace have changed enough that a current congressional discussion of employment discrimination against women would be unlikely to include the same sneering spectacle that Congressman Smith staged. This is all to the good, and I venture that the passage of

suggest that you might also favor an amendment or a bill to correct the present 'imbalance' which exists between males and females in the United States."

Then she goes on to say-and she has her statistics, which is the reason why I am reading it to you, because this is serious-"The Census of 1960 shows that we had $88,331,000$ males living in this country, and $90,992,000$ females, which leaves the country with an 'imbalance' of $2,661,000$ females."

Now another paragraph: "Just why the Creator would set up such an imbalance of spinsters, shutting off the 'right' of every female to have a husband of her own, is, of course, known only to nature. But I am sure you will agree that this is a grave injustice-"

And I do agree, and I am reading you the letter because I want all the rest of you to agree, you of the majority ....

Id at 3213-14. It is ironic that while Congressman Smith was quoting statistics showing that there were more women than men in the United States, he continued to refer to women as the "minority sex."

4 EEOC, Legislative History at 3214 (cited in note 1).

3 Interestingly, liberal supporters of Title VII rose in opposition to the Smith Amendment, fearing that the Southern strategy of making the bill more problematic would derail their primary goal of attacking racial discrimination. See Id at 3214. The ten Southern congressmen-including Congressman Smith-who successfully championed the amendment barring sex discrimination ultimately voted against the passage of the bill. See id at 3222; and Richard K. Berg, Equal Employment Opportunity Under The Civil Rights Act of 1964, 31 Brooklyn L Rev 62, 79 n 31 (1965), 
Title VII accelerated this shift in attitudes. ${ }^{6}$

All the attitudinal changes concerning women in the workplace certainly are not attributable to federal law, and one should not exaggerate the extent of the improvement. The sorry truth is that most working women today-even with the protection of law-do not feel that they are treated as equals in the workplace, and survey data indicate that they have reason for this belief. ${ }^{7}$

In a recent nationwide random sample, for example, $55 \%$ of 483 women with full-time jobs indicated that "at work, most men don't take women seriously." Of course, one cannot know whether this response indicates that most men in fact don't take women seriously or whether a majority of working women merely labor under this misconception, but the results of a study of the beliefs of business executives in 1965 and 1985 seem consistent with the women's perceptions. ${ }^{9}$ In $1965,27 \%$ of male business executives

- While Judge Posner adheres to the belief of some economists that preferences are innate and immutable, see George J. Stigler and Gary S. Becker, De Gustibus Non Est Disputandum, 67 Am Econ Rev 76 (1977), it has been widely acknowledged that laws can powerfully shape preferences, for good or ill. Gunnar Myrdal, An American Dilemma (Harper \& Row, 1944) (laws requiring segregation maintain and reinforce prejudice and discrimination). While it is commonly impossible to evaluate and compare preferences, there is an objective basis for determining that the elimination of animus-based discrimination is unambiguously good since it eliminates a social cost; that is, if we could suddenly shift to a world in which the Beckerian taste for discrimination is absent, then the social cost imposed by the psychic burden of discrimination would be eliminated. Economists are increasingly focussing upon the malleability of preferences, and the benefits derived from preferenceshaping legislation. Amitai Etzioni, The Moral Dimension: Towards a New Economics 10 (Free Press, 1988); T.A. Marschak, On the Study of Taste Changing Policies, 68 Am Econ Rev Pap \& Proc 386 (May 1978); Kenneth Dau-Schmidt, An Economic Analysis of the Criminal Law as a Preference Shaping Policy (forthcoming, Duke LJ). To the extent that Title VII has contributed to a decline in discriminatory attitudes, the law has promoted efficiency.

7 One lamentable illustration of this phenomenon occurred in 1983 in the Atlanta law firm of King and Spalding. Although a sex discrimination lawsuit against it was pending in the Supreme Court at the time, the firm entertained the notion of holding a "wet T-shirt" contest featuring the firm's female summer associates. Criticism from within led the firm to hold a swimsuit competition instead. A partner, speaking to the Wall Street Journal, said of the winner-a third-year law student from Harvard who received an offer from the firm-." "s] Goldberg, Breaking the Silence: Sexual Harassment in Law Firms, ABA J 46 (August 1989).

Lisa Belkin, Bars to Equality of Sexes Seen as Eroding, Slowly, NY Times 1, 16 (Aug. 20, 1989). See also the possibly related finding that law firms hiring at UCLA preferred to hire female summer associates but showed no statistically significant preference for female full-time associates. David Eaves, I.P.L. Png, and J. Mark Ramseyer, Gender, Ethnicity and Grades: Empirical Evidence of Discrimination in Law-Firm Interviews, $7 \mathrm{~L}$ \& Inequality 189, 211-12 (1989).

- Charlotte Decker Sutton and Kris K. Moore, Executive Women-Twenty Years Later, 63 Harv Bus Rev 42, 48 exhibit 2 (September-October 1985). 
said they would feel comfortable working for a woman; by 1985 the percentage had risen, but only to $47 \%$. The comparable figures for female executives were $75 \%$ in 1965 and $82 \%$ in 1985 . Clearly, a significant number of managerial employees would not like to work for a woman.

If Judge Posner is correct that "few employers can be ignorant any longer concerning women's abilities as workers,"10 it is difficult to attribute these findings to anything but misogyny. ${ }^{11}$ Judge Posner notes that as more women enter the labor market, we can expect misogyny to decline because male workers will sympathize with the plight of their wives and daughters. ${ }^{12}$ But the improvement from 1965 through 1985, even aided by the law, has not been so complete that women can now expect equal treatment in the workplace.

Another nationwide random sample conducted in 1977 asked 373 working women whether they felt "in any way discriminated against on [the] job" because they were women. $13.1 \%$ said "yes."13 In a 1982 survey of 648 randomly selected residents of greater Washington D.C., $86.9 \%$ of blacks and $73.7 \%$ of whites indicated-in equal percentages of men and women-that sex discrimination was still a major problem confronting women in the labor market. ${ }^{14}$ The same survey found that more than one in five whites (and one in three blacks) perceived at least some hiring discrimination against women in their workplace, and more than one in three whites (and two in five blacks) believed there was discrimination in promotion. ${ }^{15}$

That men and women are not treated equally in the labor market does not imply that legal intervention will necessarily make matters better. The law can be a cumbersome mechanism, costly to

${ }^{10}$ Richard A. Posner, An Economic Analysis of the Law of Employment Discrimination on Grounds of Sex, 56 U Chi L Rev 1311, 1321 (1989) (henceforth "Posner").

11 I assume that men and women are equally intelligent, and for a vast array of jobs, are equally productive. For an opposing view, see Steven Goldberg, Numbers Don't Lie; Men Do Better Than Women, NY Times A21 (July 5, 1989) (men score 60 points higher on the S.A.T. because they have superior spatial and mathematical aptitude).

12 Posner, 56 U Chi L Rev at 1323.

13 Peter Kuhn, Sex Discrimination in Labor Markets: The Role of Statistical Evidence, 77 Am Econ Rev 567, 569-70, 572 table 2 (1987).

14 Richard Seltzer and Edward Thompson, Attitudes Towards Discrimination and Affirmative Action for Minorities and Women 40 (Institute for Urban Affairs and Research, Howard U, 1985). The corresponding percentage of blacks and whites who indicated that racial discrimination is still a major problem facing blacks on the job market was $94.5 \%$ and $68.3 \%$ respectively. Id at 24 . In other words, whites see sex discrimination as more of a problem than race discrimination.

15 Id at $115-16$. 
implement and at times ineffective or even counterproductive in furthering its goals. The friends of laws and programs prohibiting sex discrimination in the workplace should be aware of such problems to ensure that legitimate goals are secured at the lowest possible cost. Judge Posner serves this educative function admirably by directing his considerable intellect to cataloguing every conceivable problem with laws prohibiting sex discrimination. The general conclusion of his provocative essay is that "the net effect of the cascade of laws and lawsuits aimed at eliminating sex discrimination in employment" has been to reduce social welfare and quite possibly the welfare of women as a group. ${ }^{16}$

Judge Posner raises three basic arguments against sex discrimination laws: (1) social welfare will be diminished if their goals are met; (2) the laws are ineffective in meeting their goals; and (3) to the extent that they have been successful in meeting their goals, these laws have actually harmed their intended beneficiaries. ${ }^{17}$ This essay will evaluate this collection of attacks, and offer additional views on some aspects of sex discrimination law.

Section II discusses the first argument, the heart of Judge Posner's theoretical efficiency attack on sex discrimination laws, that it is socially harmful to override the preferences of discriminators and to prohibit employers from engaging in statistical discrimination. ${ }^{18}$ I will attempt to refute this argument by showing that Title VII can promote efficiency in a number of ways: by more rapidly eliminating discriminators, by inducing beneficial productivity and supply curve shifts, and by reducing the inefficiencies associated with statistical discrimination. ${ }^{19}$ Section III then addresses a number of the specifics of Judge Posner's attack on the practical aspects of sex discrimination laws-namely that the law is costly to enforce, is often unnecessary, and has not enhanced the welfare of women. Section IV concludes with an evaluation of the relative importance of equity and efficiency considerations in assessing the desirability of antidiscrimination laws.

16 Posner, 56 U Chi L Rev at 1334.

${ }^{17}$ There is an obvious tension between Judge Posner's second and third points. I will treat these as being argued in the alternative.

${ }^{18}$ Both elements of this theoretical attack apply equally to discrimination on the basis of race or religion, as do my comments in response thereto.

19 Judge Posner documents the many avenues in addition to Title VII-from the Equal Pay Act to the Equal Protection Clause-that can underlie a sex discrimination claim. Except where further refinement is needed, I will use the term Title VII to refer generically to the federal prohibition of sex discrimination in employment. 


\section{Judge Posner's Two Major Theoretical Objections to ANTIDISCRIMINATION LAWS}

\section{A. Overriding Preferences}

The first element of Judge Posner's theoretical attack on Title VII's prohibition of sex discrimination in employment is that it interferes with economically efficient behavior by overriding the preferences of employers who discriminate. For example, if some men prefer being treated by male doctors, it would certainly interfere with their preferences-and thus reduce economic efficiency-for the government to require them to choose doctors without regard to sex. Title VII, which focuses only on employment relationships, does not prohibit individuals from choosing doctors in accordance with their preferences; but the law could still be interpreted to abridge choice in ways that many would lament. For instance, Title VII might prohibit a men's college from refusing to hire a woman to fill its only position for a staff physician, despite a preference for male doctors among some of its students. This is probably the strongest case for Judge Posner's position: the discriminatory preference here seems reasonable, and it implicates issues of privacy that are simply lacking when, say, a manager in a manufacturing plant refuses to hire women for the assembly line because, in Judge Posner's words, "he has traditional views of 'the woman's place." "20

In fact, however, the courts have distinguished between these two types of preferences, granting exceptions to the antidiscrimination laws when significant privacy interests are at stake. Thus, "same sex" employment rules have in certain circumstances been upheld as bona fide occupational qualifications permitted by Section 703(e) of Title VII. ${ }^{21}$ Furthermore, Title VII's inapplicability to firms with fewer than 15 employees also represents an attempt by lawmakers to accommodate privacy and associational concerns. Thus, a bunch of law school chums who simply want to get together and form a small, clubby, and male law firm are free to exclude female attorneys as long as the firm employs fewer than

${ }^{20}$ Posner, 56 U Chi L Rev at 1318.

${ }^{21}$ See, for example, Fesel v Masonic Home of Delaware Inc., 447 F Supp 1346 (D Del 1978) (upholding limitations on employment of male nurse's aides in a nursing home to protect the privacy interests of female residents). See also Deborah A. Calloway, Equal Employment and Third Party Privacy Interests: An Analytical Framework for Reconciling Competing Rights, 54 Fordham L Rev 327 (1985) (attempting to resolve the conflict between privacy and equal employment that arises when courts find protectable privacy interests). 
15 workers and is not a federal government contractor. ${ }^{22}$ Note that in both these instances federal law is more tolerant of discrimination on the basis of sex than on the basis of race: there is no bona fide occupational qualification exception for race under Title VII, and employers in small firms may not discriminate against blacks. $^{23}$

1. Disregarding the harm to misogynists.

If the law has sheltered preferences that seem reasonable from government interference, then the type of preference that the law thwarts is that of misogynists. But should society consider misogynists' preferences at all? Without attempting to resolve this thorny question, I will criticize one intuitively appealing argument that suggests it should not. The argument goes as follows: Judge Posner's concerns about the efficiency loss of overriding preferences represents solicitude for misogynistic preferences that deprive women of job opportunities and lower their earnings. By enacting Title VII, society has rejected the legitimacy of such preferences. Therefore-and here is where the flaw enters-efficiency is in effect redefined to give no weight to the utility of the misogynist, for this is precisely the form of behavior that the legislative judgment has determined to be improper.

This argument was once advanced by, among others, ${ }^{24}$ economist William Landes in analyzing the costs and benefits of laws prohibiting discrimination against blacks: "Psyche losses to whites should not be deducted from benefits, because by passing a fair employment law society is saying, in effect, that the psyche income from discrimination that accrues to whites should not enter society's social welfare function."25 The argument, however, contains a fatal circularity; in evaluating the costs and benefits of a law, it

${ }^{22}$ Executive Order 11246, 3 CFR 1964-65 Comp 339 (1965), as amended 3 CFR 1966-70 Comp 684 (1967), prohibits gender discrimination by federal contractors.

${ }^{23}$ Although Title VII's 15 employee limitation applies to race discrimination as well, 42 USC $\$ 1981$ (1982) still prohibits intentional discrimination on the basis of race in firms of any size. See Johnson v Railway Express Agency, 421 US 454, 459-60 (1975) (§ 1981 prohibits racial discrimination in employment by private employers, and provides a remedy independent of that established by Title VII); Patterson v McLean Credit Union, $109 \mathrm{~S}$ Ct 2363 (1989) ( $\$ 1981$ prohibits a racially discriminatory refusal to hire, although it does not extend to racial discrimination in the terms and conditions of employment).

${ }^{24}$ See Glen G. Cain, The Economic Analysis of Labor Market Discrimination: A Survey, in Orley Ashenfelter and Richard Layard, eds, 1 Handbook of Labor Economics 693, 710 (North-Holland, 1986).

${ }^{25}$ William M. Landes, The Economics of Fair Employment Laws, $76 \mathrm{~J}$ Pol Econ 507, 548 (1968). 
relies upon the law itself to justify disregarding certain costs. This is equivalent to arguing that laws prohibiting abortion prior to Roe $v W_{a d e}{ }^{26}$ were good because they achieved the benefit of protecting the fetus while imposing no cost, since any benefits to women from abortion's availability were set at zero by the law itself. ${ }^{27}$

\section{The simple, static efficiency argument against Title VII.}

If one honors all preferences (even the misogynists'), ${ }^{28}$ simple economic models support Judge Posner's theoretical position that the law is inefficient. Figure I depicts the supply and demand for female labor in a simple static model. ${ }^{29}$

28410 US 113 (1973).

27 I am not saying that we must honor the preferences of misogynists by allowing them to discriminate against women. It is certainly appropriate for society to decide that the harm to women caused by this preference is unacceptably high-which I argue below is the case. My point only addresses the issue of how one reaches the conclusion that a law forbidding sex discrimination is desirable: one cannot use the existence of the law itself to bias a cost-benefit analysis designed to establish the desirability of the law. It should be noted, however, that once the law is passed it may create a presumption that, in society's judgment, the perceived benefits of the law outweigh its perceived costs. This presumption might be rebutted by a showing that the law was actually a product of legislative failure, and reflects only the position of a minority or special interest group. This argument would have little merit with respect to Title VII's prohibition against employment discrimination, which enjoys immensely broad popular support throughout the United States. Paul Burstein, Discrimination, Jobs, and Politics (U Chicago, 1985). Conversely, the presumption might well have been inappropriate with respect to the pre-Roe $v$ Wade anti-abortion laws, which may have reflected special interest legislation. See Laurence H. Tribe, American Constitutional Law $\$ 15-10$ at 1355-56 (Foundation, $2 \mathrm{~d}$ ed 1988).

28 There is a growing consensus, even among economists, that the benefits that criminals derive from unlawful behavior should carry no weight in the social welfare function. Alvin K. Klevorick, On the Economic Theory of Crime, in J. Roland Pennock and John W. Chapman, eds: Criminal Justice 289, 293-94, 299 (NYU, 1985); Steven Shavell, Criminal Law and the Optimal Use of Nonmonetary Sanctions as a Deterrent, 85 Colum L Rev 1232, 1234 (1985); Kenneth G, Dau-Schmidt, Sentencing Antitrust Offenders: Reconciling Economic Theory with Legal Theory 99 Wm Mitchell L Rev 75, 90 (1984); George J. Stigler, The Optimum Enforcement of Laws, 78 J Pol Econ 526, 527 (1970).

${ }_{29}$ For a discussion and illustration of the use of supply and demand analysis in analyzing employment discrimination, see John J. Donohue III, Is Title VII Efficient?, $134 \mathrm{U} \mathrm{Pa} \mathrm{L}$ Rev 1411 (1986). 
Figure I:

The Supply and Demand for Female Labor With and Without Discrimination

$\$$

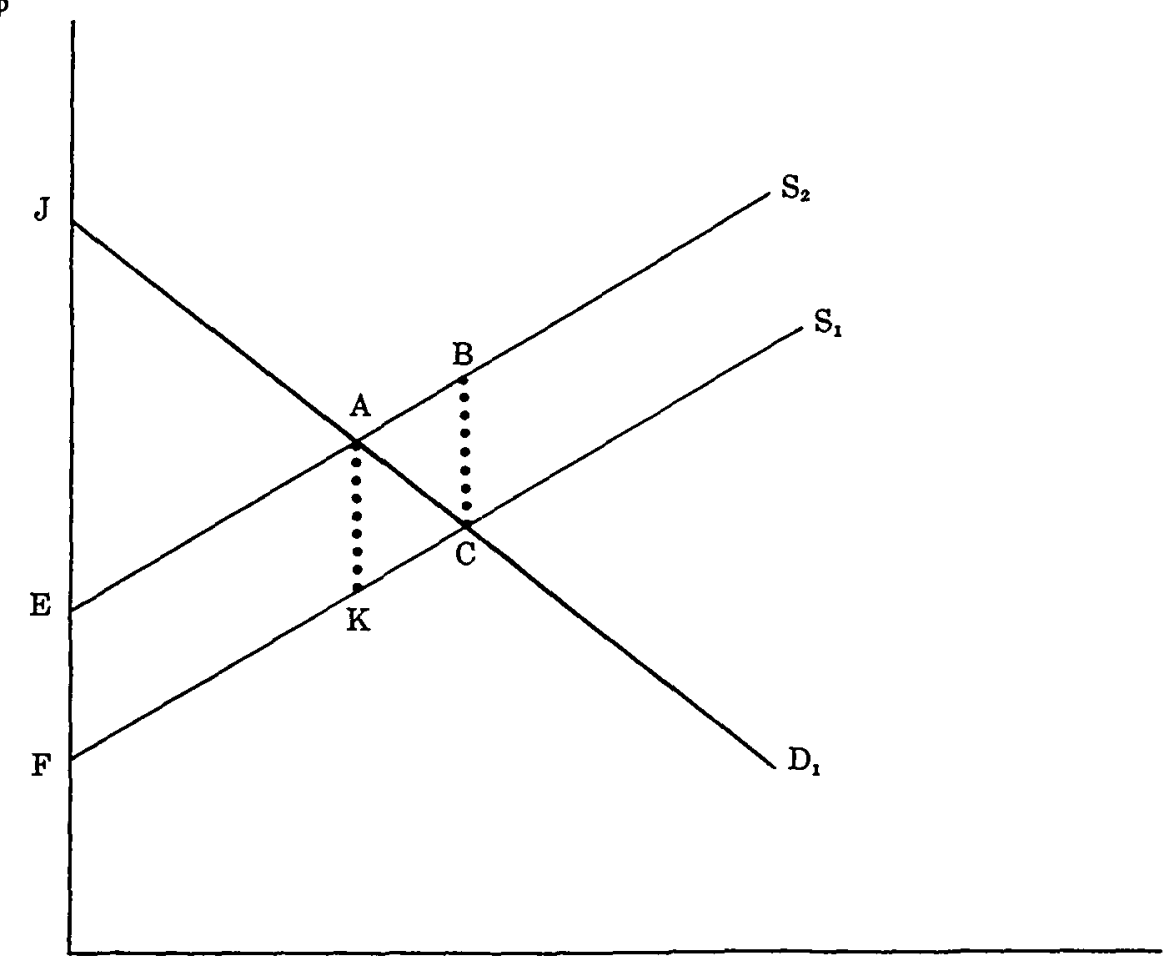

Quantity of Female Labor

By comparing social welfare with and without the antidiscrimination law, one can measure the effect of the laws on short-run social welfare. The demand curve $D_{1}$ represents the actual productivity of female workers, which by assumption equals that of similarly qualified male workers. The supply curve $S_{1}$ represents the wage that women must be paid in order to supply their labor. In a perfectly nondiscriminatory world, then, the market equilibrium wage and quantity of female labor hired would occur at point $C$, which is the intersection of $D_{1}$ and $S_{1}$. Since social welfare is depicted as the area below the demand curve and above the supply curve-in this case area FJC-social welfare is maximized at this market 


\section{equilibrium. $^{30}$}

Because many employers are not indifferent to the applicant's sex in making hiring decisions, even when there is no productivity based reason for doing so, outcome $C$ will not be attained under laissez faire. Instead, the laissez-faire equilibrium occurs at the intersection of $\mathrm{D}_{1}$ and $\mathrm{S}_{2}$ (point $A$ ). ${ }^{31}$ This is because demand curve $D_{1}$ reflects the marginal benefit from hiring additional female workers and supply curve $S_{2}$ reflects the marginal cost (including both monetary and psychic costs). As long as the marginal benefit is greater than the marginal cost (as is the case for any point to the left of point $A$ ), then the employer will benefit from hiring more female workers. If the employer were to hire female workers past point $A$, however, the supply curve would lie above the demand curve, indicating that the costs from additional hiring would outweigh the benefits.

The vertical distance $B C$ between supply curves $S_{2}$ and $S_{1}$ represents an estimate in dollars of the psychic cost to employers of hiring a woman when misogynistic tastes would lead them to prefer a man. Because of these discriminatory preferences, the monetary wage and employment level of women have fallen from point $C$ to point $K$ (the distance $A K$ representing "psychic wages" paid by the employer, but of course of no benefit to the employee), and social welfare has fallen to area EJA. But while discrimination against women unambiguously lowers social welfare, legal intervention can only make matters worse in this simple static model: if society honors all preferences, welfare is still greater under laissez faire than with an antidiscrimination law. The new supply curve $\mathrm{S}_{2}$ has replaced the nondiscriminatory supply curve $S_{1}$, both in determining the free market outcome and in determining maximum social welfare. If the passage of an antidiscrimination law increased female employment to point $C$, social welfare would fall from area

${ }^{30}$ This is evident because if the hiring of female workers stops before point $C$ has been reached, then the social welfare triangle will be less than area FJC. If the hiring continues past point $C$, then social welfare will be area FJC minus some positive area, which is necessarily less than area FJC.

${ }^{31}$ This model is derived from Gary Becker, The Economics of Discrimination (U Chicago, $2 \mathrm{~d}$ ed 1971). Intuitively, one might conceive of employer discrimination as reducing the demand for female labor rather than shifting the supply. The two approaches are, however, mathematically equivalent, and I choose to shift the supply curve for convenience. See Donohue, $134 \mathrm{U} \mathrm{Pa} L \mathrm{Rev}$ at $1415 \mathrm{n} 16$ (cited in note 29) for a formal proof of equivalence. Under this approach, the demand curve will reflect the actual productivity of female workers (rather than simply what employers are willing to pay them) and the new "supply" curve will reflect both the monetary and psychic costs that discriminatory employers must pay to hire women. 
EJA to area (EJA - CAB) because the psychic costs to the employer represented by distance $B C$ and triangle $C A B$ cannot be avoided. As long as the costs, both monetary and psychic, embodied in $\mathbf{S}_{\mathbf{2}}$ are taken into account, any interference with the market equilibrium at point $A$ will only reduce short-run social welfare.

3. Economic arguments in favor of antidiscrimination legislation.

a. The dynamic efficiency of eliminating discriminators. The analysis in subsection (2) has always struck me as incomplete, ${ }^{32}$ and I have argued elsewhere that, in a dynamic context, antidiscrimination laws can indeed be wealth-maximizing. ${ }^{33}$ This argument, which does not rely upon the implicit social condemnation of discrimination and accepts the legitimacy of discriminatory preferences goes like this: Employers who discriminate because of misogyny are not profit-maximizers, and therefore will ultimately be driven from the market. ${ }^{34}$ As the discriminators are forced out of business, social welfare will rise from area EJA to area FJC because the psychic cost of employing women has been eliminated. Consequently, there is a social benefit to be obtained by driving discriminators out of business.

In fully articulating this dynamic efficiency argument, I showed that a law penalizing discrimination will succeed in driving out the discriminators-thereby reducing the psychic costs of discrimination-even more quickly than would occur under laissez faire. The law will be efficient if the following condition holds: the social benefits of move rapidly eliminiating discriminators must outweigh the short-run social cost of overriding the discriminators'

${ }^{32}$ It must be stressed that an assumption implicit in the static analysis of subsection (2)-an assumption that is almost certainly incorrect-is that a dollar taken away from an affluent discriminating male employer and given to a relatively poorer female employee would leave social welfare unchanged. Therefore, at the very least, the added social benefits of the distributionally superior consequences of an employment discrimination law must be considered in assessing the efficient outcome.

${ }^{33}$ Although I first raised this argument in the context of a discussion of racial discrimination, it can apply directly to any type of animus-based discrimination by employers. See Donohue, $134 \mathrm{U}$ Pa L Rev 1411 (cited in note 29); Richard A. Posner, The Efficiency and Efficacy of Title VII, 136 U Pa L Rev 517 (1987); John J. Donohue III, Further Thoughts on Employment Discrimination Legislation: A Reply to Judge Posner, $136 \mathrm{U}$ Pa L Rev 523 (1987).

${ }^{34}$ Let me underscore the critical assumption that the discrimination is based on animus (or more neutrally, tastes) on the part of the employer. The market will not discipline discriminatory behavior that arises from the animus of fellow workers or customers. This type of animus will be rewarded in the marketplace. 
preferences.

Judge Posner has correctly emphasized that if the market is operating perfectly this condition should not hold, since the market should discipline the discriminators at the optimal rate. But while competitive market forces generally tend to move economic actors in the right direction, these market forces do not always operate at the optimal speed. ${ }^{35}$ This seems particularly true in the case of employment discrimination. ${ }^{36}$ In such cases, when the government knows that the ultimate equilibrium will involve the elimination of all discriminators from the market, steps taken to overcome the market frictions that retard or even prevent the attainment of the optimal nondiscriminatory outcome can be welfare-enhancing.

b. The value of improved working conditions and enhanced self-esteem. The power of the logic and the forcefulness of the empirical evidence supporting the above dynamic efficiency argument have thus far failed to persuade Judge Posner. Therefore, I will offer some additional criticisms of the simple static analysis. That analysis implicitly assumes that the underlying supply and demand curves for female labor are unaffected by the passage of an antidiscrimination law. In other words, while the law may artificially accelerate the attainment of the nondiscriminatory market equilibrium $C$ in Figure I, the "true" social costs and benefits derived from the employment of female labor are still given by demand curve $D_{1}$ and supply curve $S_{2}$. Ultimately, when all the discriminators have been eliminated, there will be no more psychic cost associated with hiring women. At this point, $S_{1}$ will be the

${ }^{35}$ Theoretical and empirical work has raised doubts about the speed at which market pressures will eliminate inefficient behavior. See Richard R. Nelson and Sidney G. Winter, An Evolutionary Theory of Economic Change 139-54 (Belknap, 1982). George A. Akerlof and Janet L. Yelien, Can Small Deviations From Rationality Make Significant Differences to Economic Equilibria?, 75 Am Econ Rev 708 (1985). Faulhaber and Baumol demonstrate that decades after the net present value formula for selecting among investment opportunities had been developed by Irving Fisher, many major firms were still not using the correct approach in their decision making. Gerald Faulhaber and William Baumol, Economists as Innovators: Practical Products of Theoretical Research, 26 J Econ Lit 577, 585 (1988).

${ }^{36}$ See John J. Donohue and Peter Siegelman, The Changing Nature of Employment Discrimination Litigation (American Bar Foundation, unpublished April 1989). James Heckman and Brook Payner have shown that over a fifty year period competitive markets in the South Carolina textile industry were not powerful enough to break down the discriminatory barriers erected to the employment of black labor. Black employment rose dramatically in this industry only after the effective date of Title VII of the 1964 Civil Rights Act. James J. Heckman and Brook S. Payner, Determining the Impact of Federal Antidiscrimination Policy on the Economic Status of Blacks: A Study of South Carolina, 79 Am Econ Rev 138 (1989). 
"true" supply curve. But the societal pronouncement that women are equal to men, as well as legislated protections against harassment and other indignities, may elevate women's self-esteem and improve life on the job to such a degree that both the demand and the supply curves for female labor shift. ${ }^{37}$ In other words, improved working conditions generated by the law can: (1) enhance labor productivity, thereby causing an upward shift in the demand curve; and (2) diminish the onerousness of work, resulting in a downward shift in the supply curve. ${ }^{38}$

37 The notion that societal pronouncements are capable of stigmatizing individuals and therefore imposing psychological harm was central to the Court's declaration in Brown $v$ Board of Education that a regime of "separate but equal" racial segregation was unconstitutional. 347 US 483, 494 (1954). If segregationist laws imposed psychological harm, then legislation asserting equality may well generate psychological benefits.

38 While the view that eliminating harassment of female workers will reduce the onerousness of work is not controversial, there is an empirical debate over the effect of improving working conditions and overall satisfaction with one's job on productivity. See M.M. Petty, Gail W. McGee, and Jerry W. Cavender, A Meta-Analysis of the Relationships Between Individual Job Satisfaction and Individual Performance, 9 Academy of Mgmt Rev 712 (1984) (finding an impressive correlation between overall job satisfaction and job performance); Michelle T. Iaffaldano and Paul M. Muchinsky, Job Satisfaction and Job Performance: A Meta-Analysis, 97 Psychological Bull 251 (1985) (concluding that there is no strong pervasive relationship between job satisfaction and job performance); Arthur $\mathrm{H}$. Brayfield and Walter H. Crockett, Employee Attitudes and Employee Performance, 52 Psychological Bull 396, 398-409 (1955) (reviewing empirical literature and finding no relationship between job satisfaction and on-the-job performance, but finding that job satisfaction does lead to somewhat greater job stability and fewer absences). Note that satisfaction will not translate into better work performance if it produces complacency. But even this satisfaction can generate benefits for employers since more satisfied workers have greater stability of employment and less frequent absences.

Recent experimental evidence supports the notion that equal opportunity laws "significantly increas[e] the effort levels of all" workers. Clive Bull, Andrew Schotter, and Keith Weigelt, Asymmetric Tournaments, Equal Opportunity Laws and Affirmative Action: Some Experimental Evidence 28 (Unpublished 1988); See also Andrew Schotter and Keith Weigelt, The Benefits of Equal Opportunity, 65 Bus and Society Rev 45 (Spring 1988). The rationale for this finding is that modern labor markets are frequently structured as tournaments in which the most productive work will earn large rewards. If employers are biased in favor of certain types of workers-for example, white males-then the preferred workers will have an advantage in the competition for the rewards, causing the favored workers to coast and the disfavored workers to assert less effort. The authors conclude that greater equity promotes efficiency.

Jonathan Leonard also presents evidence that the productivity of female workers rose relative to that of white males over the period between 1966 and 1977. Leonard observes that "the level of female schooling relative to that of males has not increased, and so cannot explain the estimated productivity ratio increase." Jonathan Leonard, Antidiscrimination or Reverse Discrimination: The Impact of Changing Demographics, Title VII, and Affirmative Action on Productivity, $19 \mathrm{~J}$ Human Resources 145, 166 (1984). While the imprecision of Leonard's productivity estimates suggests caution in relying too heavily on his findings, they are at least suggestive that some unexplained factor has led to an increase in the productivity of women workers, which is consistent with the view that the law has generated a beneficial demand curve shift. 
To simplify the discussion, I will illustrate this argument in Figure II under the assumption that only the supply curve shifts, because the showing that the law can generate benefits exceeding its costs applies a fortiori if the demand curve also shifts outward.

Figure II:

Beneficial Supply Shifts Induced

By Sex Discrimination Laws

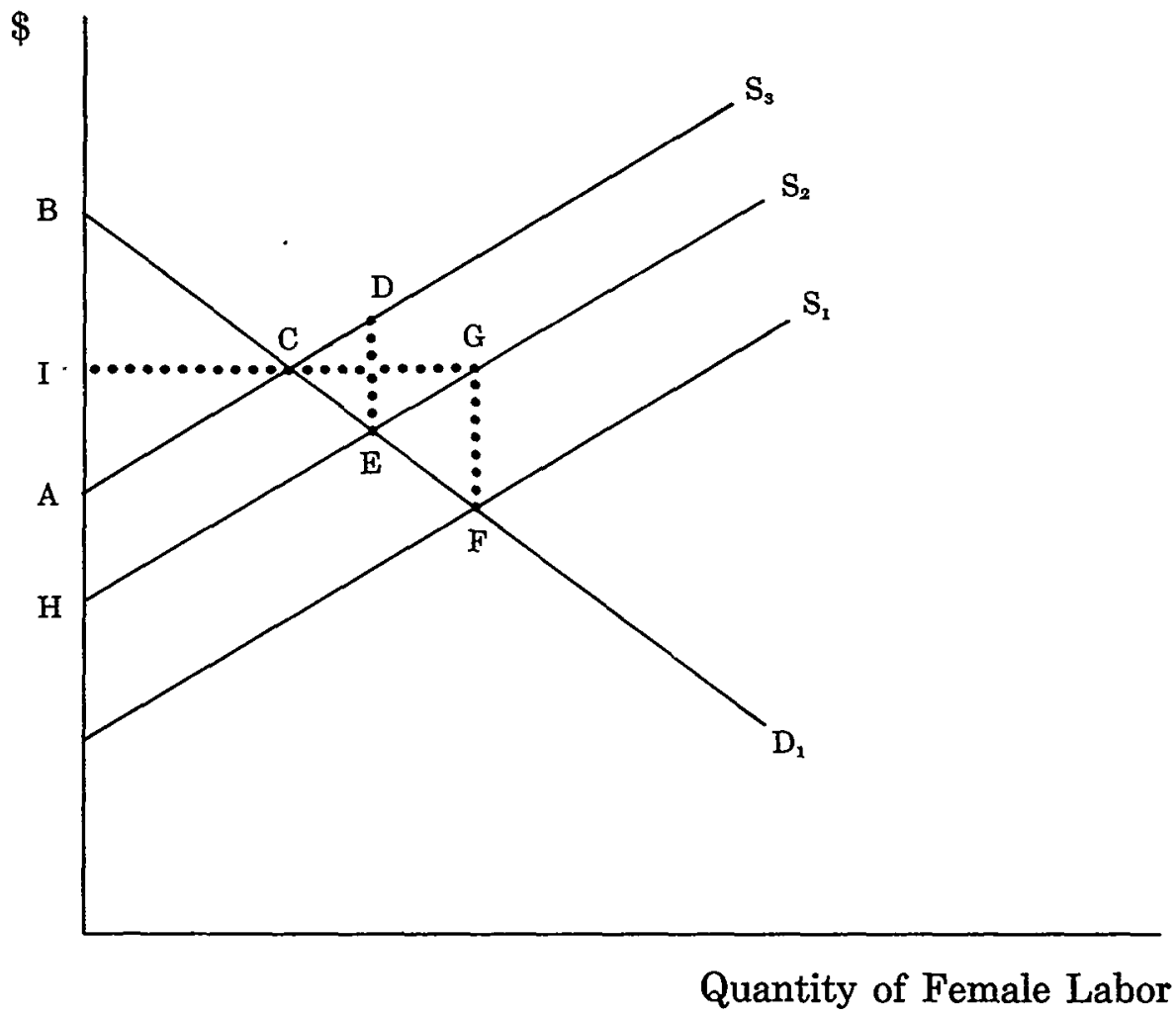

The laissez-faire equilibrium in a world with some misogyny occurs at the intersection of demand curve $D_{1}$ and supply curve $S_{3}$. The spacing on $D_{1}$ supply curve in the absence of discrimination against women would be $S_{2}$, which implies that the psychic cost from hiring an additional female employee is the vertical distance between supply curves $S_{2}$ and $S_{3}(D E)$. In the analysis presented in subsection (2) above, passage of the antidiscrimination law simply induced the achievement of the nondiscriminatory equilib- 
rium-here, the intersection of $\mathrm{D}_{1}$ and $\mathrm{S}_{2}$ at point $E$-leading to a reduction in social welfare from the laissez-faire state because the costs of hiring additional female labor beyond point A (as given by $\mathrm{S}_{2}$ ) exceed the benefits of their production (given by $D_{1}$ ). ${ }^{39}$

Now suppose that the law simultaneously induces an improvement in working conditions and self-esteem for female employees, which causes a downward shift in the supply curve of labor. The downward shift of the supply curve implies that as working conditions improve more women will be willing to work for any offered wage. To further simplify the graphical analysis, assume that the fall in the supply curve is equal in distance to the size of the peremployee psychic cost of discrimination..$^{40}$ This indicates that the new nondiscriminatory market equilibrium that the law tries to enforce is the intersection of $D_{1}$ and $S_{1}$ at point $F$, although the total (monetary plus psychic) social cost of hiring these workers is the supply curve $\mathrm{S}_{2}$ (since $G F=D E$ by assumption). Thus, social welfare under the new law is now measured by area (HBE - EGF). As long as area HACE is greater than area EGF, the law has increased social welfare. The social benefits derived from the downward shift in the supply curve, which are based on an improvement in working conditions for women, outweigh the inefficiency of overriding the preferences of discriminatory employers.

If social welfare would be increased by enacting the law, why wouldn't the employer have an incentive to prohibit discrimination and thereby capture some of the increased wealth? Before answering this question, I must emphasize that in this particular example there is no direct incentive for the employer to act because his welfare after the introduction of the law (which generates equilibrium point $F$ ) is actually lower than in the laissez-faire state (which generates equilibrium point $C) .{ }^{41}$ Of course, the Coase Theorem suggests that female employees will simply bribe employers to enforce

\footnotetext{
39 Social welfare under laissez faire was area $A B C$, and under the new law fell to area (ABC - CDE).

${ }^{40}$ In other words, $S_{2}$ is parallel to and half way between $S_{1}$ and $S_{3}$.

42 The employer's profit under laissez faire is the value of what is produced (the area under the demand curve from point $B$ to point $C$ ) less the monetary and psychic cost of hiring female labor (the area below line segment IC). Thus, the employer's profit under laissez faire is area IBC. The antidiscrimination law compels the employer to hire more women even though the total cost to him, monetary and psychic, has remained at line ICG. Therefore, the employer's profit with the law is the area under the demand curve out to point $F$ less the area under line ICG, which equals area (IBC - CGF). In other words, the law causes the profits of the discriminatory employer to fall by area CGF. This is because the surplus generated by the shifting of the supply curve from $S_{2}$ to $S_{1}$ is captured primarily by the female labor force.
} 
a contractual nondiscrimination agreement. ${ }^{42}$ But transaction costs in coordinating employees to make such bribes might prevent the attainment of the efficient outcome. ${ }^{43}$ More importantly, the very act of bribing the misogynistic employers confirms the absence of equality that is required to generate the favorable supply curve shift. It hardly instills a profound sense of equality for an employer to announce that he will hire the number of women who would be employed in the absence of discrimination (equilibrium point $F$ ), so long as these female employees compensate him for relinquishing his discriminatory practices. In other words, the very act of paying a bribe to the employer to move to point $F$ will undermine the self-esteem that is necessary to make the move to point $F$ welfare-enhancing. ${ }^{44}$ If the positive supply curve shift can only be generated by treating female employees identically to similarly productive male employees, then it cannot be obtained through a Coasean bribe paid by female employees. ${ }^{45}$

Moreover, even if employers privately prohibited discrimination against women, a legal prohibition might still be warranted

42 If private enforcement is as effective as public enforcement-which is questionable-then female employees should be willing and able to bribe employers to adopt the welfare-enhancing measures. The resulting surplus would enable the employees to improve their own welfare and still pay a bribe to employers that was sufficiently large to at least maintain the level of welfare that the employers enjoyed under laissez faire.

${ }^{13}$ In another article I presented evidence suggesting the failure of Coasean efficiency predictions based on the assumption of zero transaction costs in a particular labor market context. Specifically, in a bonus experiment designed to reduce the number of workers collecting unemployment compensation by awarding bonuses to workers or their employers if they left the unemployment rolls quickly, workers and employers not infrequently failed to achieve the efficient outcomes predicted in a world of zero transaction costs. See John J. Donohue III, Diverting the Coasean River: Bonus Schemes To Reduce Unemployment Spells, 99 Yale L J (forthcoming 1989). Just as transaction costs prevent consumers from bribing monopolists to produce the efficient quantity, female employees may be unable to bribe discriminatory employers to treat them fairly, even if efficiency would so demand.

4 The argument that improving the working conditions of women produces welfare benefits is similar to-but more persuasive than-the argument of Richard Freeman and James Medoff that unions enjoy higher wages because they improve working conditions and elevate productivity. Richard Freeman and James L. Medoff, What Do Unions Do? 162-80 (Basic Books, 1985). Freeman and Medoff must then explain why employers oppose unions if they truly raise productivity. Perhaps unions not only increase productivity but also enhance the workers' ability to capture more of the firm's surplus at the expense of management-just as the law in Figure II elevates social welfare but depresses the profits of employers. But while Freeman and Medoff must resort to transaction costs to explain why Pareto-superior outcomes are foregone, my argument is that there are some Coasean bribes that are intrinsically incapable of achieving their goal.

15 See generally John J. Donohue III, The Law and Economics of Tort Law: The Profound Revolution, 102 Harv L Rev 1047, 1068-69 (1989) (questioning Landes's and Posner's assumption that there is an effective market substitute for intentionally injuring someone). 
since public enforcement of Title VII may be superior to private enforcement of contractual promises of nondiscrimination and nonharassment. It is not a persuasive argument against the passage of Title VII that employers will have an incentive to curb the proscribed behavior anyway whenever it is efficient to do so. Certainly we do not require employers to privately enforce rules against embezzlement without the assistance of public law enforcement, though in the absence of criminal laws they would almost surely try to limit such behavior. Public enforcement of rules preventing sex discrimination and harassment may be as efficient as public enforcement of laws prohibiting embezzlement.

It is also conceivable that the effect of a public declaration of equality on the morale and self-esteem of women is far greater than the mere articulation of nondiscrimination policies by individual firms. ${ }^{46}$ Certainly, self-esteem is an important element of happiness. ${ }^{47}$ Consequently, the costs of Title VII would have to be quite high indeed before they would outweigh any significant increase in women's self-esteem. ${ }^{48}$ Moreover, there are both public good and externality elements to the elevation of women's self-esteem. ${ }^{49}$ If all firms strongly assert the value of women, then

${ }^{46}$ Chief Justice Earl Warren emphasized the significance of the psychological harm imposed by school segregation in Brown $v$ Board of Education, noting that segregation "generates a feeling of inferiority ... that may affect [the] hearts and minds [of black school children] in a way unlikely ever to be undone." 347 US at 494 . Others have also emphasized that desegregation can generate "a greater sense of personal dignity; ... greater self confidence and respect . . .; increased morale, [and] decreased self-hatred . . . ." Edward A. Suchman, John P. Dean, and Robin M. Williams, Jr., quoted in Nancy H. St. John, School Desegregation Outcomes for Children 43 (Wiley, 1975).

17 Abraham Maslow identifies self-esteem as one of the innate "higher order needs" that are essential to human fulfillment. Abraham H. Maslow, A Theory of Human Motivation, 50 Psychological Rev 370, 381-82 (1943).

18 I am quite comfortable stating that society highly values increases in the self-esteem of its citizens. The more difficult question is whether law can effect such enhancements. A generalized legal proclamation that everyone is a good and worthy human being would probably generate little psychic benefit. But if individuals are sheltered from severe forms of unequal treatment and given remedies to compensate them should such treatment occur, they may well experience positive gains in self-esteem.

On the other hand, if antidiscrimination law is carried beyond its goal of generating equal employment opportunity into the realm of advancing less qualified individuals, the law may generate harmful decreases in self-esteem among the beneficiaries of the law and exacerbate discriminatory feelings among white males. In such an event, the law would cause harmful supply and demand curve shifts.

40 One external benefit is that women who are happy with their jobs contribute to the well-being of their children. Bruno Bettelheim, Why Working Mothers Have Happier Children, Ladies' Home Journal 24 (June 1970) ("[S]o far as the child is concerned, what matters most is the mother's attitude toward working. If she hates it, the child will suffer. If she gets real satisfaction from it, the child will pick up her enthusiasm and will look at life optimistically, thus contributing to the well-being of both."); Mary C. Howell, Employed 
women's self-esteem and quite likely their productivity will rise: If one firm fails to join the chorus of respect, it may still benefit from the productivity enhancements of the general elevation of self-esteem without incurring the expense of monitoring and disciplining its misogynistic male employees. Consequently, government may be needed to prevent such free-riding by firms. Similarly, women outside the workforce may gain from the generalized affirmation of women's equality, and no firm would have an incentive to consider this benefit in deciding how strong a commitment to the equal treatment of women it wished to make.

If the law generates beneficial shifts in the supply and/or demand curves for female labor that cannot otherwise be achieved through private action, then the simple, static efficiency analysis above is incomplete because it does not incorporate such shifts. Depending upon the magnitude of any such shifts, the antidiscrimination law may well be welfare-enhancing. But is there any evidence of beneficial shifts in the supply and demand curves following the passage of Title VII? The matter is difficult to resolve since so many other factors were affecting these curves, but I have already noted Leonard's finding that female productivity rose relative to white men in the period between 1966 and $1977 . .^{\circ 0}$ In addition, the supply curve for female labor shifted outward quite dramatically after 1964 (in other words, the size of the female labor force grew substantially), ${ }^{51}$ and the law may have played at least some role in this development. Moreover, the extent of the supply curve shift, whatever its cause, has doubtless contributed to the rather small increase in the wages of women in the last two decades. Judge Posner takes this as a sign of the ineffectiveness of the law. Nonetheless, an increase in the quantity of labor supplied in the aftermath of the law's enactment would be expected to depress the monetary wage, even though the net wage would increase since the burden of working would have fallen. ${ }^{52}$

Mothers and Their Families, 52 Pediatrics 252, 258-59 (1973) (if employment increases a mother's "sense of recognized competence, achievement, and self-worth," it will assist in healthy child development).

${ }^{30}$ Leonard, $19 \mathrm{~J}$ Human Resources 145 (cited in note 38 ).

s1 24.7 million women were working in 1965 , and 52.9 million women were working at the end of 1988-an increase of $114 \%$. Over this same period the increase in the male workforce was only 63\%. Council of Economic Advisors, Economic Report of the President 346 (GPO, 1989). That female employment grew far faster than male employment without corresponding increases in female wages indicates that the increase in female employment did not result only from an outward demand curve shift.

${ }^{52}$ By net wage I mean the vertical difference between the monetary wage and the supply curve for female labor. If the monetary wage remains unchanged but the supply curve 
One of the most important things to realize about the possible supply and demand shifts which may have flowed from the passage of Title VII is that even slight shifts yield extremely large benefits. If the combined size of the upward shift in the demand curve (increased productivity) and the downward shift in the supply curve (reduced onerousness of work) is only $1 \%$, then the law has generated annual benefits of roughly $\$ 6.66$ billion. ${ }^{53}$ Certainly, this figure dwarfs the estimated $\$ 400$ million in enforcing the law. ${ }^{54}$

c. Sexual harassment. Although he is somewhat equivocal on the issue, Judge Posner also appears to believe that laws prohibiting sexual harassment are unnecessary since the problem "is largely self-correcting." J5 Judge Posner argues that employers have an incentive to curb harassment because it lowers productivity: "[W]ith more and more women workers, sexual harassment becomes more costly. Apart from the impact on productivity . . . , a larger fraction of the work force is offended by it, so the total compensating differential that the employer must pay its female employees rises." Tho Though this argument has some force, it fails to account for the severe informational problems associated with sexual harassment. Certainly if women knew in advance that taking a particular job would expose them to harassment, the employer would be harmed because women would either shun the firm or demand higher wages sufficient to compensate for the burden of harassment. In either event, the labor costs of the employer would rise. But it is unlikely that complete information will be available. The molesters rarely begin their assaults before the female worker is hired, nor do they advertise what is to come. Moreover, victims of sexual harassment have little or no incentive to furnish information about their plight to current or potential fellow workers. Disclosure may be embarrassing or bring censure from others. In the

has dropped, the net wage is thereby elevated.

ss Women represented $45.1 \%$ of those employed in 1988 . Since they earn roughly $60 \%$ of what men earned, women received approximately $27.1 \%$ of the total wages and salaries paid in 1988 of $\$ 2.46$ trillion, which equals roughly $\$ 666$ billion. A combined $1 \%$ shift in the supply and demand curves of female labor will therefore generate social benefits of $\$ 6.66$ billion.

54 See text at note 64 .

ss Posner, 56 U Chi L Rev at 1321. But see Judge Posner's more sympathetic argument that "the case for prohibiting sexual harassment may actually be stronger from an economic standpoint than the case for prohibiting conventional sex discrimination. ... The most efficient method of discouraging sexual harassment may be by creating incentives for the employer to police the conduct of its supervisory employees, and this is done by making the employer liable." Id at [Now P. 41-43]

se Id at 1331-32. 
absence of legal protection, the response to sexual harassment will frequently be either to quietly endure or to quietly leave-neither of which would provide useful information to the employer or to prospective workers. Therefore, while Judge Posner is quite correct that in a world of perfect information the market will discipline firms that permit the harassment of female workers, the law will certainly be a welcome ally when the lack of perfect information undermines the protection afforded by the market.

\section{B. Barring Statistical Discrimination}

Judge Posner also portrays the prohibition of statistical discrimination as inefficient. There are statistical differences between men and women workers-for example, women live longer but miss more time due to illness each year. Because these factors are relevant to worker productivity and compensation, it is inefficient for employers to ignore them. Certainly, if an employer knew that a particular applicant for a job would be likely to miss more time from work than another, we would not expect her to deem the two applicants equal. Efficiency would require that she pay them differently to reflect their different values. Does this suggest then that women should receive lower salaries, since statistical evidence indicates that they have a lower value on average than male workers? ${ }^{57}$

Not necessarily. When two individual workers are contracting for employment, the one who is known to require more sick leave can take measures to enhance her health; presumably, the worker would take these precautions since doing so would yield greater benefits through higher wages. But when a worker is offered a lower wage because "women take more sick leave," this is not an option. The employer has determined that women are more prone to sickness, and therefore will be paid less. Since compensation is

s7 The concern, of course, is that women are on average less productive than men. As one analyst has noted, however, men are more likely than women to be alcoholics and/or criminals, which of course are not ideal traits for employees. Audrey Freeman, Those Costly 'Good Old Boys', NY Times 21 (July 12, 1989). Freeman invites the reader to consider how many maternity leaves Exxon could have funded with the billions of dollars that were lost because the captain of the Valdez was drunk. Indeed, Exxon spent $\$ 1$ billion to clean up 4 of the 11 million gallons of oil that spilled into Prince William Sound. Timothy Egan, Alaska Oil Cleanup Winds Down With Many Beaches Still Fouled, NY Times 1 (September 10, 1989). Since men are more than twice as likely as women to be alcoholics, Freeman, NY Times at 21, the expected losses associated with alcohol use on the job are likely to be at least twice as great for men as for women-and perhaps greater if female alcholics tend to remain out of the workforce. 
based not on individual but group characteristics, workers will lack incentives to take the optimal health measures. Individual investments in human capital will therefore be distorted. Similarly, if employers do not want to train women for top corporate positions because they will "quit to have children," the incentive to invest in human capital will be inefficiently impaired for women who do not plan to leave their jobs. This inefficiency will exist even if the firm is correct on average in relying upon its statistical information. ${ }^{58}$ Thus, while acting on statistical information may be profit-maximizing for the firm, it may still be inefficient for society. ${ }^{\text {s9 }}$

Judge Posner has focused upon the efficiency of discrimination and the concomitant inefficiency of legal prohibitions of such behavior. I have tried to focus on the inefficiency of discrimination and the attendant efficiency gains provided by the laws. Discrimination against women can impair productivity and degrade working conditions. Without a law such as Title VII too few women will

ss If the statistical inference is inaccurate, there is certainly no cost in being prevented from relying upon it. Employers may be led astray because they have inaccurate information about differences between the sexes, they ignore certain costs that men impose at a higher rate (see note 57), or they are simply inept at applying statistical rules. Interestingly, while prior to the early 1970 s women did apparently quit their jobs more frequently than men in order to raise children, there is evidence that this is no longer the case. See John J. Donohue III, Determinants of Job Turnover of Young Men and Women in the U.S.-A Hazard Rate Analysis, 6 Res in Population Econ 257 (1987); John J. Donohue III, The Changing Relative Hazard Rates of Young Male and Female Workers (unpublished 1989); Robert Cherry, Discrimination: Its Economic Impact on Blacks, Women, and Jews 141-42 (Lexington, 1989) ("[N]o evidence exists to support the proposition that, other things being equal, women have higher rates of turnover [than men].") (emphasis in original). See generally Mayer G. Freed and Daniel D. Polsby, Privacy, Efficiency, and the Equality of Men and Women: A Revisionist View of Sex Discrimination in Employment, 1981 Am Bar Found Res J 585, 633-35 (arguing that we should prohibit those forms of privately efficient statistical discrimination that are based on self-fulfilling prophecies). Even if employers have all of the correct information about employees, the empirical evidence suggests that individuals are quite poor at applying Bayes' Theorem. Steven C. Salop, Evaluating Uncertain Evidence with Sir Thomas Bayes: A Note for Teachers, $1 \mathrm{~J}$ Econ Perspectives 155 (1987); Ames Tversky and Daniel Kahneman, Judgment Under Uncertainty: Heuristics \& Biases, 185 Science 1124 (1974). Therefore, a benefit from the prohibition of statistical discrimination is the reduction in the inaccurate uses of race and sex as informational proxies.

ss Shelly J. Lundberg and Richard Startz, Private Discrimination and Social Intervention in Competitive Labor Markets, 73 Am Econ Rev 340, 346-47 (1983); Stewart Schwab, Is Statistical Discrimination Efficient?, 76 Am Econ Rev 228, 233 (1986). This effect was first predicted in the work of Michael Spence, who showed that while employers might find it efficient to rely on credentials such as the level of education in making employment decisions, this behavior would cause an inefficient overinvestment by workers in obtaining the credential (or signal, to use Spence's term). Michael Spence, Job Market Signaling, 87 Q J of Econ 355, 363-64 (1973). When workers are unable to obtain the signal, because it is some immutable trait such as race or sex, then the effect of statistical discrimination is likely to impair the incentive to make productivity-enhancing investments. 
be hired, and their wages will be too low. Moreover, statistical discrimination in conjunction with these welfare losses will tend to cause inefficient investment by women in their own human capital, because the women will not be fully compensated for additional investments. As a pure theoretical matter, then, laws forbidding sex discrimination increase efficiency by increasing the productivity and self-esteem of women; improving the quality of the working environment, thereby elevating the workers' surplus or net wage; and eliminating inefficient interferences with the human capital investment decisions of women. The attendant inefficiencies are the interference with the (primarily) misogynistic preferences of employers, fellow workers, and customers, and the added costs to the employer from being unable to use statistical information about women and men in making employment decisions. Final resolution of the efficiency question would then depend on the weighing of these efficiency gains and losses. ${ }^{60}$

Unlike Judge Posner, who begins with a set of premises that lead to the conclusion that sex discrimination laws must reduce welfare, I begin with a different set of premises that, absent empirical refutation, provide a theoretical basis for believing that the laws are socially beneficial. Of course, if one believes that the market drives out discriminators at the optimal rate (despite the evidence from the South Carolina textile industry); that women will be able to induce employers to eschew discrimination when doing so will yield beneficial supply and demand shifts and generate optimal investments by female workers; and that female workers have full information about the prospects for harassment by different employers before accepting a particular job; then the market has already performed the cost-benefit analysis and a sex discrimination law is necessarily inefficient. Since I am very dubious about each of these premises, I think it is important to assess the possible costs and benefits of the law.

\section{The Law In Practice}

Judge Posner stresses that even if sex discrimination would in theory produce the socially optimal result, there are many reasons to be concerned about the way the laws work in practice. I will turn, then, from the desirability of the goals of sex discrimination

${ }^{60}$ For an attempt to provide rough estimates of some of these quantities in order to evaluate the efficiency of prohibiting race discrimination, see Donohue, $136 \mathrm{U} \mathrm{Pa} \mathrm{L}$ Rev 523 (cited in note 33). 
laws to a discussion of the means selected to achieve these goals and the extent to which the goals have been realized.

\section{A. Enforcement Costs}

In arguing above that laws forcing employers to disregard the sex of applicants and workers would increase social welfare, I assumed that the laws were costlessly enforced. When these costs are introduced, the possibility exists that the social benefits of achieving gender-neutral employment decisions will be outweighed by the costs.

The costs of eliminating sex discrimination include the adjudicative and administrative costs associated with the legal prohibition as well as the costs of interfering in labor market decisions. The first category includes the costs of: (1) the administrative effort in the Office of Federal Contract Compliance Programs (OFCCP); (2) the roughly 30,000 complaints filed with the Equal Employment Opportunity Commission (EEOC); and (3) the 3,000 cases filed in the federal courts alleging discrimination on the basis of sex. ${ }^{61}$ A very rough estimate of these costs would be around $\$ 200$ million per year. ${ }^{62}$ The second category includes the costs of erroneous legal determinations that, for example, incorrectly compel an employer to hire a less qualified female worker; the cost of hiring additional female workers simply to avoid being sued; and, as Judge Posner notes, the cost of not hiring additional female workers simply to avoid being sued. ${ }^{63}$ While the magnitude of these costs is unknown, if we make the admittedly speculative assumption that the magnitude is roughly the same as the magnitude of the administrative costs, the total cost of implementing Title VII's

61 About 90,000 charges of employment discrimination are filed each year with the EEOC, and about 9,000 actions are brought in federal district court. Of these, roughly onethird are complaints of sex discrimination. Donohue and Siegelman, The Changing Nature of Employment Discrimination Litigation (cited in note 36 ).

${ }^{62}$ If each case filed in the EEOC imposed total costs of $\$ 5,000$ on litigants and the agency, and each federal district court case imposed total costs of $\$ 15,000$, the combined total would be $\$ 195$ million per year. See generally Donohue, $136 \mathrm{U} \mathrm{Pa} \mathrm{L}$ Rev at 545-46 (cited in note 33). Moreover, the total budget of the OFCCP in 1988 came to $\$ 49.4$ million, of which one-third-or $\$ 16.5$ million-might be attributed to enforcement of the prohibition of sex discrimination. Budget of the United States Government, Fiscal Year 1990 Appendix at I-P11 (GPO, 1989).

${ }^{63}$ This final point is based on the finding that it is more likely that an employer will be sued for employment discrimination if a protected worker is fired than if a protected worker is not hired. Accordingly, it is possible that employers would prefer not to hire women (or blacks) simply to avoid the prospect of a lawsuit in the event that the employer later needed to discharge workers. Posner, $136 \mathrm{U}$ Pa L Rev 517 (cited in note 33); Donohue and Siegelman, The Changing Nature of Employment Discrimination Litigation (cited in note 36). 
proscription against sex discrimination would equal roughly $\$ 400$ million per year-less than $\$ 8$ per female worker. ${ }^{64}$ Therefore, as long as the net theoretical advantage of the sex discrimination laws-the excess of the welfare gains over welfare losses described above-were at least $\$ 400$ million, recognizing implementation costs would not change the theoretical conclusion that the law is efficient.

\section{B. The Law Has Not Enhanced the Welfare of Women}

Under the analysis outlined above, if the theoretical benefits of a sex discrimination law outweigh the theoretical costs by more than the estimated implementation costs of $\$ 400$ million, then the theoretical basis for such legislation has been established. But theory and practice at times diverge, and Judge Posner marshals evidence that the theoretical benefits have not been secured. There are several dimensions to his attack.

1. The laws don't enhance the wages and employment levels of women.

Judge Posner argues that the law has not moved us significantly closer to the nondiscriminatory equilibrium (in other words, point $C$ in Figure I). While the evidence on this point is mixed, I agree with Gunderson's summary, which Judge Posner quotes: "Clearly, the evidence does not unambiguously indicate that the EEO [Equal Employment Opportunity] initiatives of Title VII were a resounding success, although there is some evidence of a positive effect on the earnings and occupational position of women. There is also some evidence that the legislation is more effective when it is strictly enforced and when the economy is expanding." Judge Posner concludes from this statement that we would be better off without Title VII. Others will conclude that we need stronger enforcement. From the evidence that Judge Posner presents, it is uncertain which conclusion is justified.

The position that more enforcement is needed is tenable only if additional enforcement-which is certainly costly-is likely to improve labor market conditions for women. Some recent informa-

64 With 52.4 million women working at the end of 1988 , the implementation cost per female worker would equal \$7.63 per year. Council of Economic Advisors, Economic Report of the President 346 (GPO, 1989).

${ }^{8 s}$ Morley Gunderson, Male-Female Wage Differentials and Policy Responses, $27 \mathrm{~J}$ Econ Lit 46, 61 (1989), cited in Posner, 56 U Chi L Rev at 1324-25. 
tion compiled by economist Finis Welch is illustrative. ${ }^{66}$ Firms with at least 100 workers are required by law to file detailed annual reports-called EEO-1 reports-with the EEOC. The EEOC uses this information in conducting its enforcement activities by targeting firms that seem to have low ratios of "protected" workers in comparison to the available labor pool. Welch has shown that between 1966 and 1980 the representation of black and female workers increased significantly more in firms subject to the EEO-1 reporting requirement than in the non-reporting sector. This increased flow of protected workers to the EEO-1 firms is most dramatic for black women but is also significant for white women, as shown in Table $\mathrm{I}^{67}$

Table I:

Representation of Protected Groups in Firms Reporting to the EEOC*

\begin{tabular}{|l|r|r|r|r|r|}
\hline & 1966 & 1970 & 1974 & 1978 & 1980 \\
\hline Black Men & 91.8 & 112.5 & 123.1 & 128.4 & 126.4 \\
Black Women & 91.5 & 118.7 & 141.2 & 144.8 & 154.4 \\
White Women & 90.1 & 93.4 & 95.8 & 97.6 & 96.7 \\
\hline
\end{tabular}

* Figures are percentages of protected workers in EEO-1 reporting firms divided by the corresponding percentages for white men. Ratios are multiplied by 100 . Black women were almost $10 \%$ less likely to work in reporting compared to non-reporting firms in 1966 , and were almost $55 \%$ more likely to work in reporting firms in 1980. Welch, Affirmative Action and Discrimination at 176 (cited in note 66).

Table I demonstrates that proportionally more blacks and women have entered firms subject to EEO-1 reporting requirements, presumably because of the increased governmental scrutiny of hiring in these firms. Indeed, Jonathan Leonard has shown that among firms reporting to the EEOC, there is greater hiring of "protected" workers the greater the federal monitoring. Thus, government contractors-who are subject to additional scrutiny by the OFCCP-hire a still greater percentage of blacks and women. ${ }^{68}$

68 Finis Welch, Affirmative Action and Discrimination, in Steven Shulman and William Darity, Jr., eds, The Question of Discrimination 153, 175-76 (Wesleyan, 1989).

67 Welch derived the figures in Table I in the following manner: In 1966, 52.7\% of all white men working in private firms worked in firms that were subject to the EEO-1 reporting requirements. At the same time, $47.5 \%$ of white women workers worked in these same firms. The ratio of these two numbers-47.5/52.7-equals $90.1 \%$. In other words, the proportion of white women working in these firms is $90.1 \%$ of the percentage of white men working in EEO-1 firms. Over time, this proportion rose to $96.7 \%$ in 1980 . Id.

so Leonard writes: "Over a 6-year period [from 1974 to 1980] the employment of members of protected groups grew significantly faster in contractor than in non-contractor establishments." Jonathan S. Leonard, The Impact of Affrmative Action on Employment, $2 \mathrm{~J}$ 
These results clearly suggest that more intense government enforcement does increase the demand for black and female labor.

One might wonder whether this conclusion is consistent with the finding that Title VII has generated only modest employment and wage gains for women. It is. Since the sector that is not subject to EEO-1 reporting is so large, the enforcement efforts have tended merely to shift employment patterns by moving blacks and women into the covered sector. But the move by female workers into the EEO-1 reporting sector is evidence that government enforcement has improved the status of female workers in those firms, since presumably women would not have gone to these firms unless lured by more attractive working conditions or compensation. Moreover, if women's wages have not risen, then their conditions of employment must have improved. This is precisely the condition that I argued above must be satisfied for the law to induce beneficial productivity and supply curve shifts. The evidence of the flow of protected workers into EEO-1 firms at least raises the possibility that discriminatory managers and employers are flowing in the opposite direction, into the increasingly white male non-reporting sector. This exodus would both enhance the working conditions of women and reduce the psychic costs of discrimination to the misogynistic employers-perhaps the best of all possible worlds from Judge Posner's perspective. On the other hand, to the extent that the problem with the laws forbidding sex discrimination is that they have not increased the wages and employment level of women, there is a remedy: extend the coverage of Title VII to all workers by eliminating the exclusion for workers in firms of less than 15 employees, and increase the number of firms monitored by the EEOC and the OFCCP.

2. Women don't benefit from having their wages and employment levels increased.

Judge Posner argues that "sex discrimination law may not have improved the net welfare of women even if it has somewhat reduced the amount of sex discrimination." on the conclusion that these laws are inefficient, and therefore to the extent that they elevate women's wages, they simultaneously depress men's wages. If the laws are efficient, however, as I have argued they are, the unpleasant tradeoff between the welfare of

${ }^{69}$ Posner, 56 U Chi L Rev at 1325 (emphasis in original). 
men and women that Judge Posner envisions is unlikely to exist-there should be more for everyone. But even if the tradeoff is real, I still question the view that women do not benefit.

Judge Posner argues that the economic interdependence of men and women implies that "women derive a benefit from an increase in the income of a husband or other male relative (son, father, brother, etc.), even if no part of the increased income is consumed by the woman." and all consumption within the household were joint, "[t]hen discrimination against women in the labor force would be compensated for completely in the home, for while wives' wages would be lower than in a nondiscriminatory regime, wives would benefit dollar for dollar from the correspondingly higher wages of their husbands."71 But even if Judge Posner's admittedly extreme assumptions were universally true, ${ }^{72}$ his conclusion might not follow. The women in Judge Posner's hypothetical may be married only because sex discrimination makes them financially dependent upon men. If the elimination of sex discrimination removed the financial burden, a greater number of women might not choose to marry (or remain married) and Judge Posner's assumed interdependence would at least to some degree be undermined.

Moreover, even if all women were married and all consumption were joint, wives would not necessarily have the same prefer-

70 Id at 1316.

71 Id at 1317.

72 Of course we are far from a world in which all women are married, and the condition of the millions of women raising children alone is not one of "interdependence," but of striking independence even from men with legal obligations of support. According to the Census Bureau,

A substantial portion of the 8.8 million women with children from an absent father were never awarded support payments for their children. That is, 3.4 million mothers were totally dependent for the support of their children on sources other than the children's father. ... .

[T] here were 6.4 million mothers either wanting or due child support payments for their children in 1985, with only 51 percent of them actually receiving any amount of payment.

Of the women who did receive child support for their children in 1985, the mean amount of payment was $\$ 2,220$, about 15 percent of their average total money income [of $\$ 14,780]$. . .

Very few of the women eligible for alimony or maintenance payment were awarded them. ... There were 19.2 million ever-divorced or currently separated women as of spring 1986. Only about 2.8 million, or 15 percent, were awarded (or had an agreement to receive) alimony or maintenance payments; the remaining 85 percent were never awarded payments. ...

U.S. Bureau of the Census, Current Population Reports, Series P-23, No. 154, Child Support and Alimony: 1985 (Supplemental Report) 3-5 (GPO, 1989). 
ences about consumption as their husbands. The husband may want a hunting lodge in Maine while the wife would prefer a cottage on the Cape. And even though both parties will get enjoyment from either purchase, my guess is that the couple is more likely to end up hunting if the husband controls greater financial resources. $^{73}$ Thus, women will not be indifferent to whether sex discrimination increases men's wages at the expense of women's wages.

Judge Posner goes on to suggest that, "if women are more altruistic on average than men, the increase in men's welfare resulting from an increase in their wives' income will be less than the decrease in women's welfare resulting from a decline in their husbands' income, even if the increase and decrease are identical in dollar terms." ${ }^{44}$ In other words, the law may not only be needless because men and women have interdependent utilities, but it may be harmful because women are altruistic. But this argument is puzzling. Even if women are more altruistic, their husbands may not be the targets of their generosity. Instead, their greater altruism may be manifested by spending more on their children than their husbands would wish. If such is the case, then by lowering women's wages, sex discrimination will hurt not only working mothers, but their children as well. Furthermore, even if women's bountiful altruism does extend to the welfare of their husbands, there is still no reason to believe that wives would be harmed by a law that increases their wages at the expense of their husbands' wages, for wives can always give the surplus back to their spouses. In this way a wife would experience the altruistic pleasure of giving far more immediately than she would if she simply perceived that her husband earned more money than she did. ${ }^{75}$ On the other hand, if

${ }^{73}$ Victor Fuchs addressed this issue in the following manner:

Consider a couple who are bargaining (explicitly or implicitly) over how the household's income will be spent and how household chores will be allocated. Game theory assumes that, other things being held constant, the strength of each participant in the bargaining situation will depend on how well off each would be if they fail to reach agreement-in this case, if they divorce .... The stronger the individual's situation outside of marriage, the stronger his or her bargaining position within marriage.

Victor R. Fuchs, Women's Quest for Economic Equality 71 (Harvard, 1988). Since, as Lenore Weitzman has emphasized, women generally fare worse than men in divorce, and as indicated above, they cannot rely upon their ex-husbands for economic support, sex discrimination laws should aid women's bargaining position within marriage. Lenore J. Weitzman, The Divorce Revolution (Free Press, 1985). See also Howell, 52 Pediatrics at 255-56 (cited in note 49) (the employment of a wife increases the likelihood that she will assume a more powerful role in the family because of her increased self-esteem and economic contribution).

74 Posner, 56 U Chi L Rev at 1327 (footnote omitted).

${ }^{75}$ This is merely an application of the Coase Theorem. Given the low transaction costs 
wives do not in fact donate their excess earnings to their husbands, it shows that they are happier with the higher earnings that prohibitions on sex discrimination can bring them. In either case, the utility of working wives would seem to be unambiguously elevated by their increased wage.

Judge Posner concludes by observing that, "if by reducing the wages of men sex discrimination law propels more wives into the job market, with the result that (since they still bear the principal burden of household production) they work harder, have fewer children, and have less stable marriages, it is not clear that they are better off on balance than they were when their husbands had higher wages and they stayed home."76 Moreover, Judge Posner states that "housewives, being economically identified with their husbands, are hurt by efforts to reduce sex discrimination." ${ }^{\prime 7}$ But if married working women, housewives, and all working men are hurt by sex discrimination laws, one would imagine that groups would be organizing to repeal the laws against sex discrimination, which seems hardly the case. ${ }^{78}$ Perhaps the answer is that the antidiscrimination laws have generated efficiency gains sufficient to enhance the welfare of working women without reducing that of other groups.

\section{The Relevance of Both Equity and Efficiency}

Although in this essay I have tried to emphasize the disagreements between my position and that of Judge Posner, I believe that he is certainly correct that the costs of substantial interference with competitive markets-whether for labor or wheat or cocaine-can be quite high. And policymakers should certainly be aware of these costs, whether they are voting for antidiscrimination laws or agricultural price supports or tougher drug laws. But high

involved, women can always undo the effect of the law by simply turning over their extra income to their husbands.

78 Posner, 56 U Chi L Rev at 1335.

77 Id at 1333.

${ }^{28}$ A nationwide random sample of 1,025 women conducted in June 1989 by the New York Times revealed strong support for equal rights for women in response to the question: "What should be the most important goal for women's organizations?" Although $33 \%$ of the women had no opinion, the three answers that drew the largest responses were (1) equality on the job (27\%), (2) equal rights (14\%), and (3) child care $(5 \%)$. No other issue was mentioned by $5 \%$ of the respondents. Belkin, NY Times 1, 22 (August 20, 1989) (cited in note 8).

On the other hand, Judge Posner's position is not entirely without support in this survey. Forty-nine percent of 483 women with full-time jobs say "women have had to give up too much to get ahead." Id. 
costs may at times be offset by higher benefits. I have offered two arguments that antidiscrimination laws may be efficient-one based on the dynamic efficiency of driving discriminators from the market more quickly and one based on the added productivity (enhancing labor demand) and improved working conditions (leading to increased labor supply) to be gained by shielding employees from employer animus.

The focus on efficiency may seem a needless exercise, however, to those who deem equity rather than efficiency to be the guiding principle in the area of employment discrimination. ${ }^{79}$ Moreover, our judgments about the value and optimal implementation and interpretion of discrimination laws will certainly be influenced by whether equity and efficiency considerations push in the same direction, or, if they in fact conflict, by the size of the efficiency burden. Society's willingness to allow equity considerations to trump efficiency will necessarily depend on the costs that such action would entail. Indeed, this message even emerges from John Rawls's A Theory of Justice. ${ }^{80}$

While my discussion has held out the possibility that Title VII's prohibition of sex discrimination enhances both equity and efficiency, Judge Posner believes that there is an efficiency price that must be paid. But vague assertions of efficiency losses will not likely overcome the now deeply ingrained notion in American jurisprudence, indeed in the very concept of modern day America, that every individual should be free to advance as far as her talents will permit-a view quite at odds with the notion that discriminatory males should be able to close off employment opportunities for women because of misogynistic preferences. While such equitable concerns would not likely overcome an efficiency loss measured in the hundreds of billions of dollars, I have never seen any evidence

79 But, a frequent refrain in the Congressional debate in support of Title VII was that a federal ban on employment discrimination would also enhance economic efficiency. For example, Hubert Humphrey declared that:

Racial prejudice in employment is one of the most wasteful practices for the economy

... Every bit of evidence we have in connection with fair employment practice laws indicates that such a statute not only is good law, good morals, and good labor-management practice, but it also is good economics.

110 Cong Rec 6549 (March 30, 1964). See also Michael E. Gold, Griggs' Folly: An Essay on the Theory, Problems, and Origin of the Adverse Impact Definition of Employment Discrimination and a Recommendation for Reform, 7 Indus Rel L J 429, 580-82 (1985) (citing additional evidence on the importance of economic factors in the passage of Title VII); Donohue and Siegelman, The Changing Nature of Employment Discrimination Litigation (cited in note 36 ).

${ }^{80}$ Rawls tempers his radical egalitarianism when the attendant efficiency loss harms the poor. John Rawls, A Theory of Justice (Belknap, 1971). 
to suggest the cost of prohibiting sex discrimination could impose a burden anywhere near this amount.

I would like to conclude by offering some words of reassurance to those who fear that Judge Posner's antagonism toward Title VII's prohibition of sex discrimination might lead him to interpret the law's mandate grudgingly when exercising his judicial responsibilities. In this regard, consider the sex discrimination case Riordan $v$ Kempiners ${ }^{81}$ in which the trial judge directed a verdict for the defendants without permitting the plaintiff to compare her pay to that of several fellow male workers. Writing for the Seventh Circuit, which reversed the trial court decision, Judge Posner stated:

Proof of [intentional] discrimination is always difficult. Defendants of even minimal sophistication will neither admit discriminatory animus nor leave a paper trail demonstrating it; and because most employment decisions involve an element of discretion, alternative hypotheses (including that of simple mistake) will always be possible and often plausible. Only the very best workers are completely satisfactory, and they are not likely to be discriminated against-the cost of discrimination is too great. The law tries to protect average and even below-average workers against being treated more harshly than would be the case if they were of a different race, sex, religion, or national origin, but it has difficulty achieving this goal because it is so easy to concoct a plausible reason for not hiring, or firing, or failing to promote, or denying a pay raise to, a worker who is not superlative. A plaintiff's ability to prove discrimination indirectly, circumstantially, must not be crippled by evidentiary rulings that keep out probative evidence because of crabbed notions of relevance or excessive mistrust of juries. ${ }^{82}$

Judge Posner's evident solicitude for the rights of plaintiffs in sex discrimination cases $^{83}$ is evocative of Justice Oliver Wendell

81831 F2d 690 (7th Cir 1987).

${ }^{82}$ Id at 697-98.

83 Judge Posner has written opinions in nine appellate court cases dealing with sex discrimination, and in seven of the nine he voted in favor of the.plaintiff. Furthermore, the two sex discrimination cases in which Judge Posner ruled against the plaintiff were both 3-0 decisions. The only sex discrimination case in which Judge Posner ever dissented was $U A W$ $v$ Johnson Controls, 886 F2d 871(7th Cir 1989), where the majority upheld the dismissal of a Title VII challenge to a firm's fetal protection policy that barred all non-sterilized women from working in a manufacturing division that involved exposure to lead. Judge Posner's dissent cautioned that "by affirming [the district judge's granting of the defendant's motion for summary judgment] on this scanty basis we may be encouraging incautious employers to 
Holmes's desire to faithfully interpret the Sherman Antitrust Act, of which he was always highly dubious. Holmes once disclosed privately: "I hope and believe that I am not influenced by my opinion that it is a foolish law. I have little doubt that the country likes it and I always say ... that if my fellow citizens want to go to Hell I will help them. It's my job." ${ }^{84}$ Since time has shown that, when properly interpreted, the antitrust laws serve an important social function, we are all the more indebted to Justice Holmes for his wise judicial philosophy. I hope the judgment of history on sex discrimination laws will show that Judge Posner's reservations were similarly unfounded, but in any event, we should all respect his unmistakably Holmesian jurisprudence.

adopt fetal protection policies that could endanger the jobs of millions of women for minor gains in fetal safety and health." Id at 908. Judge Posner has clearly shown no sign of hostility to sex discrimination plaintiffs.

84 Letter of Oliver Wendell Holmes to Harold J. Laski, March 4, 1920, in Mark DeWolfe Howe, ed, 1 Holmes-Laski Letters 248-49 (Harvard, 1953). 